\title{
PROFESSIONAL IDENTITY AMONG NURSES AT GOVERNMENTAL HOSPITALS IN PORT SAID CITY
}

\author{
Prof. Samia Mohammed Abd Ala Adam'; Dr .Abeer Elsayed Mohammed Berma²; \\ Samia Gaper Elkenany Ibrahim ${ }^{3}$
}

Professor of Nursing Administration, Faculty of Nursing, Ain shams University ${ }^{1}$ Assistant professor of Psychiatric Nursing and Mental Health, Faculty of Nursing, Port

Said University ${ }^{2}$

(B.Sc Nursing), Master Degree in Nursing Administration, Port-Said University ${ }^{3}$

\begin{abstract}
Background: Professional identity is fundamental to nursing practice and sets basis for the professionalization of nursing. Aim: The aim of the study was assess of professional identity among nurses in port- said city. Subjects and Method: A descriptive design was utilized to conduct this study. The study sample was carried on 360 nurses (port-said general hospital 260 and El-zohour general hospital 110). The data was collected by using two tools; a self- administered structured interviewing questionnaire and the professional identity scale. Results: The results of this study showed that about three quarters of the studied nurses had a satisfactory professional image, also assertive domain were satisfactory, and the majority of the studied nurses were satisfied regarding self-responsibility domain. The study concluded that; the total studied nurses had overall satisfactory level. Moreover, there was a statistical significant relation between age and years of experience of the studied nurses with their overall professional identity scale. Recommendations: The study recommended that, the need to make nursing professionals individually responsible for their training, increasing their ability to learn and adding to their knowledge, as an indispensable resource for personal and professional growth. Also, further studies should also take patients' contributions into consideration and focus on patient outcomes.
\end{abstract}

Keywords: Assertiveness, Professional identity, Professional image, Self responsibility. 


\section{INTRODUCTION}

Identity in nursing defined as the development within nurses of an internal representation of people-environment interactions in the exploration of human responses to actual or potential health problems, which evolves throughout professional nurses' careers (Cook et al. 2003). Nurses learn from their work experiences and professional interaction with colleagues. They observe behaviors, attitudes, and norms required for social interactions and professional roles and functions used by people employed in the profession and adopt a sense of professional belonging (Colbeck, 2008).

The development of professional identity is a continuous process that begins with admission to the nursing program and evolves throughout one's professional career in a dynamic and fluid process where interacting relationships of education and practice lead to self-reflection, growth, and human flourishing; that process must be consistent with the profession's history, goals, and codes of ethics while "distinguishing the practice of nurses from that of other health care providers".

professional identity involves the internalization of core values and perspectives recognized as integral to the art and science of nursing. These core values become selfevident as the nurse learns gains experience, reflects, and grows in the profession. Internalization of ethical codes of conduct is imperative. The nurse embraces these fundamental values in every aspect of practice while working to improve patient outcomes and promote the ideal of the nursing profession Baker, (2011).

There are always some issues in the profession that can lead to changes in professional identity and experienced nurses' viewpoints towards professional identity, these issues set forth by different authors include gender, social, historical, cultural, political and organizational aspects (Hoeve et al., 2014).

\section{Significance of the study}

Nursing education is essential for professional identity Hoeve et al, (2014) believed that, the nurses achieve professional identity through education and work environment. Thus, it is essential to investigate how nurses construct their professional identity during career, and how this can be developed and strengthened for nursing as a profession. Additionally, investigating this concept is essential to the development of nursing as a profession. Hence, this study was assess the professional identity among nurses. 


\section{AIM OF STUDY :}

The aim of the study was assess of professional identity among nurses in port- said city.

\section{SUBJECTS AND METHOD:}

\section{Research design}

A descriptive research design utilized for the current study.

\section{Study setting:}

The present study was conducted at governmental hospitals in Elzohor hospital and Port Said general hospital which affiliated to Ministry of Health.

\section{Study subjects :}

The study population was include all head and staff nurses in the previously mentioned hospitals. there is 360 currently assigned to work. They are distributed as 31 head nurses and 329 staff nurses. Port Said general hospital 260 and El-zohour general hospital 110.

\section{Tools of data collection:-}

Tool of data collection included two tools:

\section{Tool: The socio demographic and personal data questionnaire:}

developed by the researcher include personal and job characteristics of the study sample. It consisted of 11 questions related to (age, gender, social status, hospital name, department, job title, years of experience, qualifications, and in-services training programs, why join the nursing profession, monthly income )

\section{Tool II: The professional identity scale:}

The professional identity scale adopted from Ali, (2004) to assess nurses' professional identity. It consisted of 56 items and classified into three dimensions; which are professional image include27 items; assertiveness include 25 items and self responsibility 4 items.

\section{The scoring system:}

Item were scored on 5 points as a Likert scale ranged from strongly disagree (0), disagree (1), neutral (2), agree (3), strongly agree (4). Items were considered in the data analysis. Nurses' professional identity was rated on third levels as high professional identity more than 190, moderate professional identity from 168 to190, low professional identity less than 168 . 


\section{Operational Design:}

The operational design includes preparatory phase, content validity and Reliability, pilot study.

\section{Validity}

The tools were ascertained by a jury composed of five experts in nursing administration, psychiatric field. Their opinions were elicited regarding the tool layout, parts and items.

\section{Reliability}

Cronbach's alpha coefficient was calculated to assess the reliability of tool II the developed tools through their internal consistency ,alpha $=0.88$

\section{Pilot study}

Pilot study was carried out after the development of the tools and before starting the data collection. It included 36 nurses and was conducted from the 112/2018 to the $15 / 2 / 2018$. The pilot study was carried out to test the clarity, applicability and feasibility of the study tools, to estimate the needed time to complete the tools and to find out any problems that might interfere with the data collection. After obtaining the results of the pilot study, the necessary modifications were done. The ambiguous items were omitted, and others were modified according to the nurses responses. The final form was then developed.

\section{Ethical considerations}

At the initial interview, each potential subject was informed about nature, purpose, benefits of the study, and informed that thier participation is voluntary. Confidentiality and anonymity of the subjects were also assured through coding of all data. Each participant had right to withdrawal from the study at any time. The researcher assured that the data collected, and information will be confidential and would be used only to improve their health and for the purpose of the study.

\section{Field work}

The tools were distributed to the study respondents in their work settings by the researcher. the researcher was assess the nurses of professional identity level using questionnaire and scale. After explained the purpose of the study and assure the respondents anonymity of answers and the answer was used for scientific research and was confidential. 


\section{Administrative design:-}

Before the study carried out: An official letters from the Faculty of Nursing, Port-Said University will be directed to the responsible authorities of the study settings to take their permissions to conduct the study after explaining its purpose to take their permission and gain their cooperation.

\section{Statistical design:}

The used tests were

1 - Student t-test

For normally distributed quantitative variables, to compare between two studied groups 1 - Chi-square test

For categorical variables, to compare between different groups

2 - Fisher's Exact or Monte Carlo correction

Correction for chi-square when more than $20 \%$ of the cells have expected count less than 5

3-MC -monte carlo

\section{RESULTS:}

Table (1): shows that $45.8 \%$ of the total studied nurses aged between 25-35 years with a mean age $35.97 \pm 9.19$ years. Concerning gender, it was observed that $95 \%$ of the total studied nurses are female. Regarding to level of education, it was noticed that more than three quarters $(80.3 \%)$ of the total studied nurses had diploma. In relation to job description of the studied nurses, the majority $(85 \%)$ of them are nurses. The results also clarified that $45.8 \%$ of the total studied nurses had experience in nursing field ranged from5-15 years with a mean of $17.18 \pm 9.76$, as they reported. Furthermore, the same table demonstrated $84.2 \%$ of the total studied nurses are married. Regarding monthly income, $90.6 \%$ of the total studied nurse admitted that they receive insufficient monthly income. Eventually, the table explained that $99.7 \%$ of all studied nurses live in urban areas.

Table (2): displays that slightly more than two thirds (67.2\%) of the studied nurses had a moderate level of professional image, slightly more than three quarters (77.2\%) had a moderate level of assertiveness, $60.8 \%$ had a high level of self-responsibility, and $74.4 \%$ of total studied nurses had a moderate level of professional identity.

Table (3): puzzles out the relationship between overall professional identity of the studied nurses and their demographic data. As exhibited in the table, there was a statistical significant relation between age of the studied nurses and the overall professional identity scale at Port Said general hospital where $\mathrm{p}=0.001^{*}$. Moreover, there was a statistically significant 
differences between years of experience of the studied nurses and the overall professional identity scale at Port Said general hospital where $\mathrm{p}=0.012^{*}$. Also, the same table illustrated that there was a statistically significant relation between marital status of the studied nurses and the overall professional identity scale at Port Said general hospital where $p=0.031^{*}$. No other statistically significant association could be detected in this table.

Table (4) reports the relationship between overall professional identity and clinical training of the studied nurses. As displayed in the table, there was a statistically significant relation between administrative training of the studied nurses and overall professional identity for nurses at El-zohor general hospital. Furthermore, the current table, showed that, there was a statistically significant relation between choice of nursing and overall professional identity scale of the studied nurses in Port Said general hospital and El-zohor general hospital where $p$ $=0.002^{*}$ and $0.031^{*}$

Table (5) accentuates correlation coefficient between levels of professional identity and demographic data total studied nurses in both hospitals. As observed in the table, there was statistically significant correlation between assertiveness and age of the studied nurses where $\mathrm{p}=0.033^{*}$. Also, there was statistically significant correlation between overall professional identity and age of the studied nurses where $\mathrm{p}=0.024^{*}$. Furthermore, there was statistically significant correlation between professional image and level of education of the studied nurses where $\mathrm{p}<0.001^{*}$. Also, there was statistically significant correlation between overall professional identity and level of . 
Table (1):Frequency and percentage distribution of the studied nurses regarding to their socio demographic characteristic $(n=360)$

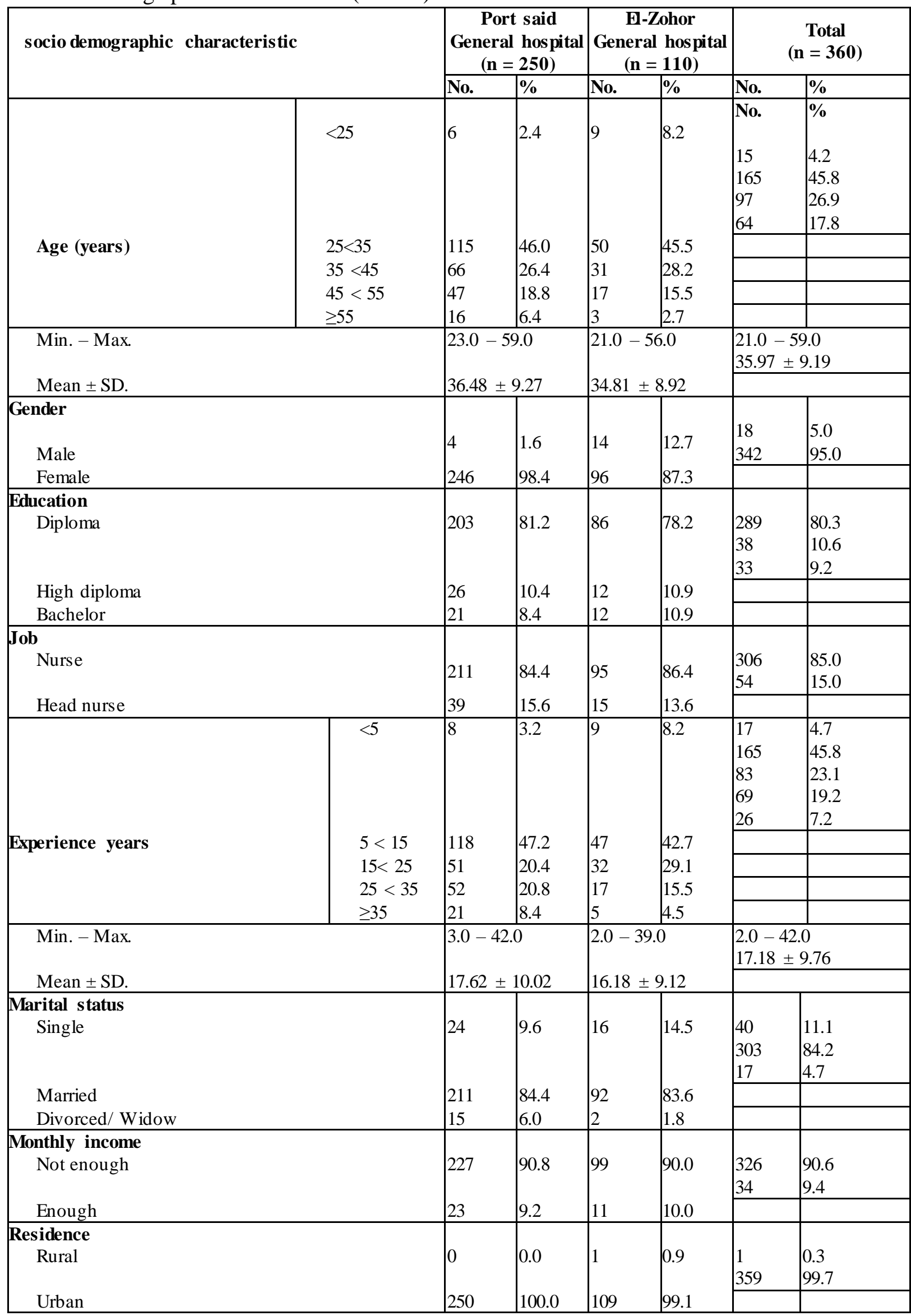


Table (2): Levels of professional identity among the studied nurses $(n=360)$

\begin{tabular}{|c|c|c|c|c|c|c|c|c|}
\hline \multirow[t]{2}{*}{ Professional identity } & \multicolumn{2}{|c|}{$\begin{array}{c}\text { Total } \\
(\mathbf{n}=\mathbf{3 6 0})\end{array}$} & \multicolumn{2}{|c|}{\begin{tabular}{|c|}
$\begin{array}{c}\text { Port said General } \\
\text { hospital } \\
(\mathrm{n}=\mathbf{2 5 0})\end{array}$ \\
\end{tabular}} & \multicolumn{2}{|c|}{\begin{tabular}{|c|}
$\begin{array}{c}\text { El-Zohor General } \\
\text { hospital } \\
(\mathbf{n}=\mathbf{1 1 0})\end{array}$ \\
\end{tabular}} & \multirow[t]{2}{*}{$\chi^{2}$} & \multirow[t]{2}{*}{$\mathbf{p}$} \\
\hline & No. & $\%$ & No. & $\%$ & No. & $\%$ & & \\
\hline Professional image & & & & & & & & \\
\hline$<50$ Low & 0 & 0.0 & 0 & 0.0 & 0 & 0.0 & $7.262^{*}$ & $0.007^{*}$ \\
\hline $50-70$ Moderate & 242 & 67.2 & 157 & 62.8 & 85 & 77.3 & & \\
\hline$\geq 70$ High & 118 & 32.8 & 93 & 37.2 & 25 & 22.7 & & \\
\hline Assertiveness & & & & & & & & \\
\hline$<50$ Low & 8 & 2.2 & 4 & 1.6 & 4 & 3.6 & $17.911^{*}$ & $<0.001^{*}$ \\
\hline $50-70$ Moderate & 278 & 77.2 & 180 & 72.0 & 98 & 89.1 & & \\
\hline$\geq 70$ High & 74 & 20.6 & 66 & 26.4 & 8 & 7.3 & & \\
\hline Self-responsibility & & & & & & & & \\
\hline$<50$ Low & 15 & 4.2 & 10 & 4.0 & 5 & 4.5 & 1.332 & 0.514 \\
\hline $50-70$ Moderate & 126 & 35.0 & 83 & 33.2 & 43 & 39.1 & & \\
\hline$\geq 70 \quad$ High & 219 & 60.8 & 157 & 62.8 & 62 & 56.4 & & \\
\hline $\begin{array}{l}\text { Overall profession } \\
\text { identity }\end{array}$ & & & & & & & & \\
\hline$<50$ Low & 2 & 0.6 & 0 & 0.0 & 2 & 1.8 & $16.703^{*}$ & $\begin{array}{l}\mathrm{MC}_{\mathrm{p}} \\
<0.001^{*}\end{array}$ \\
\hline $50-70$ Moderate & 268 & 74.4 & 174 & 69.6 & 94 & 85.5 & & \\
\hline$\geq 70 \quad$ High & 90 & 25.0 & 76 & 30.4 & 14 & 12.7 & & \\
\hline
\end{tabular}

$\chi^{2}$ : Chi square test MC: Monte Carlo

$\mathrm{p}$ : $\mathrm{p}$ value for comparing between the two groups

*: Statistically significant at $\mathrm{p} \leq 0.05$ 
Table (3): Relationship between overall professional identity and demographic data of the studied nurses $(n=360)$.

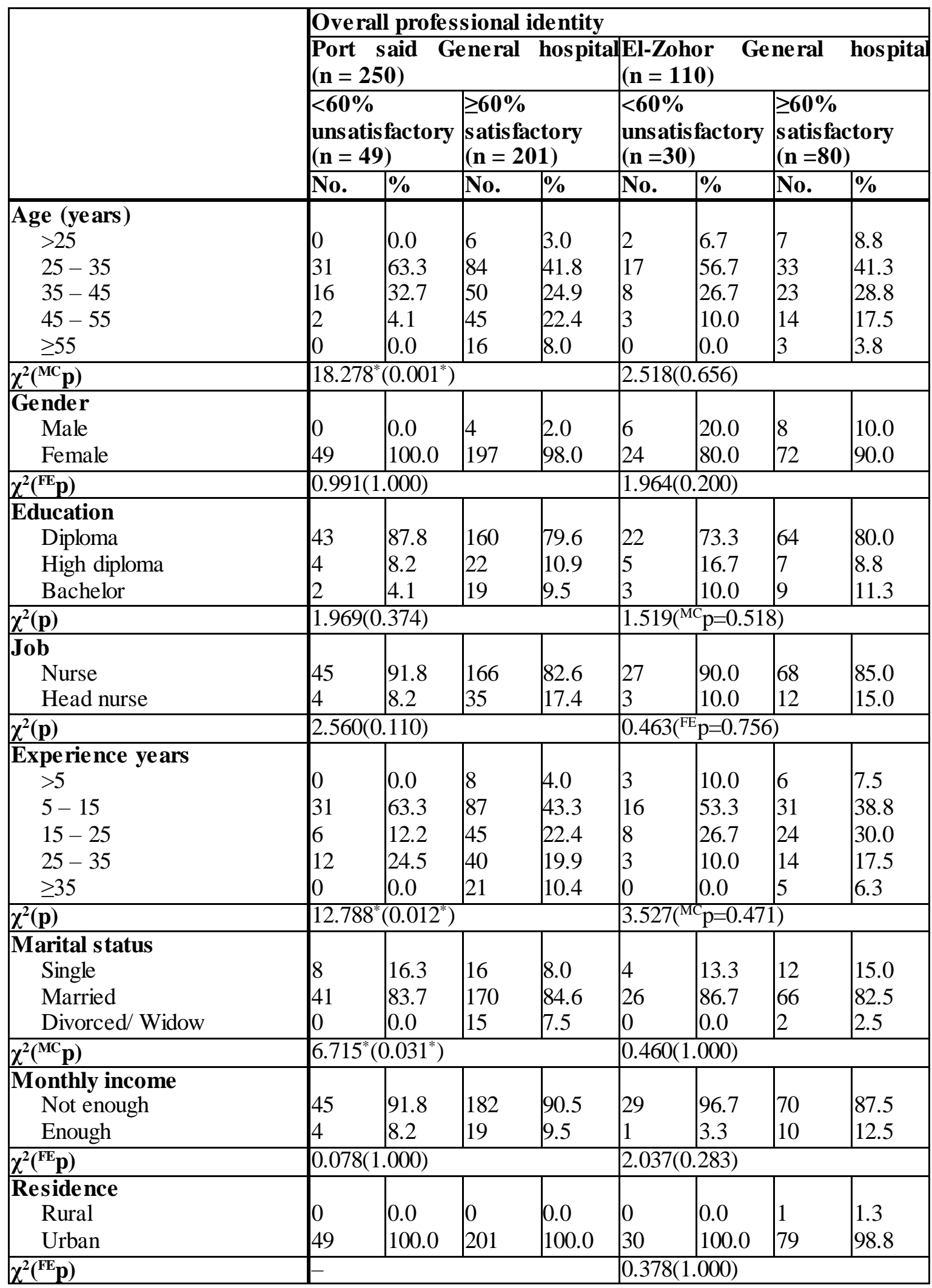

$\chi^{2}$ : Chi square test

value for comparing between the two categories $\leq 0.05$
FE: Fisher Exact p: $p$

*: Statistically significant at $\mathrm{p}$ 
Table (4):Relationship between overall professional identity and clinical training of the studied nurses $(\mathrm{n}=360)$

\begin{tabular}{|c|c|c|c|c|c|c|c|c|}
\hline & \multicolumn{8}{|c|}{ Overall professional identity } \\
\hline & \multicolumn{3}{|c|}{$\begin{array}{l}\text { Port said General } \\
(n=250)\end{array}$} & \multirow{2}{*}{$\begin{array}{l}\text { hospita } \\
\text { ctory } \\
\text { 1) }\end{array}$} & \multicolumn{3}{|c|}{$\begin{array}{l}\text { El-Zohor General } \\
(\mathbf{n}=110)\end{array}$} & \multirow{2}{*}{$\begin{array}{l}\text { hospital } \\
\text { ctory }\end{array}$} \\
\hline & \multicolumn{2}{|c|}{$\begin{array}{l}<60 \% \\
\text { unsatisfactory } \\
(n=49)\end{array}$} & $\begin{array}{l}\geq 60 \% \\
\text { satisfactory } \\
(n=201)\end{array}$ & & \multicolumn{2}{|c|}{$\begin{array}{l}<60 \% \\
\text { unsatisfactory } \\
(\mathrm{n}=30)\end{array}$} & $\begin{array}{l}\geq 60 \% \\
\text { Satisfactory } \\
(\mathrm{n}=\mathbf{8 0})\end{array}$ & \\
\hline & No. & $\%$ & No. & $\%$ & No. & $\%$ & No. & $\%$ \\
\hline Adminis trative training & & & & & & & & \\
\hline Yes & 10 & 20.4 & 55 & 27.4 & 4 & 13.3 & 30 & 37.5 \\
\hline No & 39 & 79.6 & 146 & 72.6 & 26 & 86.7 & 50 & 62.5 \\
\hline$\chi^{2}(\mathbf{p})$ & \multicolumn{4}{|c|}{$0.990(0.320)$} & \multicolumn{4}{|c|}{$5.967^{*}\left(0.015^{*}\right)$} \\
\hline Quality training & & & & & & & & \\
\hline Yes & 6 & 12.2 & 39 & 19.4 & 2 & 6.7 & 18 & 22.5 \\
\hline No & 43 & 87.8 & 162 & 80.6 & 28 & 93.3 & 62 & 77.5 \\
\hline$\chi^{2}(\mathbf{p})$ & \multicolumn{4}{|c|}{$1.368(0.242)$} & \multicolumn{4}{|c|}{$3.677(0.055)$} \\
\hline Education before university & & & & & & & & \\
\hline General & 2 & 4.1 & 11 & 5.5 & 1 & 3.3 & 7 & 8.8 \\
\hline Technical & 47 & 95.9 & 190 & 94.5 & 29 & 96.7 & 73 & 91.3 \\
\hline$\chi^{2}\left({ }^{\mathrm{FE}} \mathbf{p}\right)$ & \multicolumn{4}{|c|}{$0.155(1.000)$} & \multicolumn{4}{|c|}{$0.949(0.443)$} \\
\hline $\begin{array}{l}\text { Cause of choicing nursing } \\
\text { education }\end{array}$ & & & & & & & & \\
\hline $\begin{array}{l}\text { Desire for nursing } \\
\text { profession }\end{array}$ & 12 & 24.5 & 99 & 49.3 & 5 & 16.7 & 34 & 42.5 \\
\hline Easy to get a job & 22 & 44.9 & 74 & 36.8 & 18 & 60.0 & 29 & 36.3 \\
\hline Pressure from parents & 15 & 30.6 & 25 & 12.4 & 6 & 20.0 & 16 & 20.0 \\
\hline Ease of curriculum & 0 & 0.0 & 3 & 1.5 & 1 & 3.3 & 1 & 1.3 \\
\hline$\chi^{2}\left({ }^{\mathrm{MC}} \mathbf{p}\right)$ & \multicolumn{4}{|c|}{$14.050^{*}\left(0.002^{*}\right)$} & \multicolumn{4}{|c|}{$8.071^{*}\left(0.031^{*}\right)$} \\
\hline
\end{tabular}

$\chi^{2}$ : Chi square test

MC: Monte Carlo

FE: Fisher Exact

$\mathrm{p}$ : $\mathrm{p}$ value for comparing between the two categories $\quad *$ : Statistically significant at $\mathrm{p} \leq 0.05$ 
Table (5):Correlation between levels of professional identity and demographic data of total studied nurses in both hospitals $(n=360)$

\begin{tabular}{|c|c|c|c|c|c|c|c|c|}
\hline & \multicolumn{8}{|c|}{ Professional identity (\% score $)$} \\
\hline & \multicolumn{2}{|c|}{$\begin{array}{l}\text { Professional } \\
\text { image }\end{array}$} & \multicolumn{2}{|c|}{ Assertiveness } & \multicolumn{2}{|c|}{$\begin{array}{l}\text { Self- } \\
\text { responsibility }\end{array}$} & \multicolumn{2}{|l|}{ Overall } \\
\hline & $\mathbf{r}$ & p & $\mathbf{r}$ & $\mathbf{p}$ & $\mathbf{r}$ & $\mathbf{p}$ & $\mathbf{r}$ & p \\
\hline Age (years) & 0.103 & 0.051 & $0.112^{*}$ & $0.033^{*}$ & 0.084 & 0.110 & $0.119^{*}$ & $0.024^{*}$ \\
\hline Education & $0.195^{*}$ & $<0.001^{*}$ & $0.115^{*}$ & $0.029^{*}$ & 0.072 & 0.174 & $0.166^{*}$ & $0.002^{*}$ \\
\hline Experience years & 0.049 & 0.358 & 0.077 & 0.144 & 0.035 & 0.511 & 0.067 & 0.204 \\
\hline $\begin{array}{l}\text { Experience } \quad \text { years }(>5 \\
\geq 35)\end{array}$ & 0.057 & 0.279 & 0.096 & 0.070 & 0.026 & 0.625 & 0.079 & 0.134 \\
\hline Monthly income & -0.013 & 0.801 & -0.039 & 0.458 & -0.025 & 0.635 & -0.029 & 0.577 \\
\hline
\end{tabular}

r: Pearson coefficient

*: Statistically significant at $\mathrm{p} \leq 0.05$

\section{DISCUSSION:}

Dynamic and positive professional identity that has its roots in one's choice can lead to personal, social, and professional evolution. Nursing is one of the most critical professions in the health sector, and the nurses preferably must have accepted their roles before entering this profession. They are expected to work based on common values that represent their commitment and allegiance to their profession and the society. Therefore, the nursing staff should have enough knowledge regarding their profession (Kabeel\& Eisa, 2018). The aim of the current study was to assess professional identity level among nurses at governmental hospital in Port Said City. To discuss the results of the current study.

Concerning frequency and percentage distribution of the studied nurses regarding to the overall professional identity scale, the current results explained that, more than three quarters of the studied nurses had a satisfactory professional image. In my humble opinion, the high percentage of satisfaction among the studied nurses regarding the professional image may be attributed to the pride and interest of the nursing staff themselves in their profession. where most of the studied nurses declared that they were proud of being in nursing career, care for helping and guiding new colleagues to learn new skills, respect and cooperate with all members of health team, care to participate in medical and nursing conference or seminar, always talk in low voice, concern about 
updating my nursing and medical information and concerned to be a good model in front of colleagues. All of the aforementioned items in the table, are the essential and basic elements for enhancing and promoting professional image, so, the studied nurse might be had such high level of satisfaction regarding professional images due to such items.. This finding came in the line with the work conducted by Jarrah (2013)about "Perceptions ofassociate Nursing Studentstowards Nursing Profession in Balqa Applied University, Jordan", observed that the associate nursing students had a significant favourable understanding about the image of the nursing profession.It also agreed with the cross sectional survey done by Patidar et al (2011)to explore the understanding of outgoing nursing students across nursing profession which revealed that perception of nursing profession between nursing students is variable towards positive side. Furthermore, Masih and Gulzar( 2016) in their study which entitled "Nurses' Self Perception about their Public Image in a Metropolitan City, Karachi, indicated thatthe participants' perception of their public image was ranked positive but differed in degree by the three components of the tool.

The present study found that there were statisticallysignificant association between age of the studied nurses and the overall professional identity scale at Port said General Hospital where $\mathrm{p}=0.001^{*}$. Moreover, there was a statistically significant difference between years of experience of the studied nurses and the overall professional identity scale at Port said General Hospital. Also, the same table illustrated that there was a statistically significant difference between marital status of the studied nurses and the overall professional identity scale at Port said General Hospital.

This result may be due to retaining knowledge and experience among staff nurses who had more years of experience and had brawny emphasis and influence on other staff. Also, old, experienced staff nurses had several opportunities for professional development and promotion which promote their identity. In other words, it can be said that the highest in the age lead to more stable personality additional to higher solution with problems. Furthermore, older age by repeating the experiences for nurses reinforce professional values. Kanefuji, and Nakatani (2017) found out that Significant difference with the professional identity were noted for "age", "years of experience of the studied group.

In the same context, the current findings detected that, there was a statistically significant variation between administrative training of the studied nurses and overall 
professional identity for nurses at El-Zohor General hospital. Furthermore, there was a statically significant differences between choice of nursing and the overall professional identity scale of the studied nurses in Port said General hospital and El-Zohor General hospital. Furthermore, there was a statically significant differences between choice of nursing and the overall professional identity scale of the studied nurses in Port said General hospital and El-Zohor General hospital. This finding came in agreement with Poorchangizi et al (2017) who conducted a study about" The significance of professional worth from clinical nurses' perspective in hospitals of a medical university in Iran ", showed that a statistically significant relationship was observed between total score of professional identity of the nurses with the training clinical courses attendance Moreover, Mohtashami et al (2015) in the study which named" a Survey of Correlation between Professional Identity and Clinical Competency of Psychiatric Nurses", revealed that positive and significant relationship between professional identity and clinical competency.

\section{CONCLUSION:}

lightly more than half of the studied nurses had a moderate level of professional image and high level of self-responsibility. and the highest percentage of the studied nurses were satisfied regarding self-responsibility domain. slightly more than three quarters had a moderate level of assertiveness. Also, the findings revealed that the total studied nurses had overall satisfactory level concerning professional identity.

\section{RECOMMENDATIONS:}

In the light of the findings of the present study, the following recommendations are suggested:

- Responsible health authorities in the mental health field should encourage nurses to attend continuing education in the form of workshops, conferences and review update in professional identity

- Organizing a plan for in service education .

- Encourage nurses to attend the different training programs .

- The concept of nurse's professional identity requires more attention, awareness, and is to be emphasized in nursing schools and faculties curricula, with clarification of its positive impact on nurses' satisfaction and nursing care associated with better patient outcomes and satisfaction. 
- Provide a library with recent scientific books and magazines in an Arabic language and budget should be allowed every year for the educational activities of nurses . Nurses should be allowed to choose to work in the nursing field, to ensure better nursing interventions and interactions .

- Develop staff nurses professionally through boosting up the assertive behavior.

- It is essential to develop strategies to improve the leadership in nursing. It is very important for new nurses to have the opportunity to progress into leadership and management positions after undergoing training and preparation.

- Replication of this study is recommended using a wider probability sample and different settings.

- Future research should also take patients' contributions into consideration and focus on patient outcomes.

\section{REFERENCES:}

Ali, A. (2004). Developing a tool for assessing nurses' professional identity, unpublished master degree thesis, Cairo University, Egypt.

Apesoa-Varano, E. C. (2007). Educated caring: The emergence of professional identity among nurses. Qualitative Sociology, 30(3), 249-274.

Colbeck, C. L. (2008). Professional identity development theory and doctoral education. New Directions for Teaching and Learning, 2008(113), 9-16.

Cook, T. H., Gilmer, M. J., \& Bess, C. J. (2003). Beginning students' definitions of nursing: An inductive framework of professional identity. Journal of Nursing Education, 42 (3) $311-317$

Dehghanzadeh, S., Dehghan Nayeri, N., \& Khajeh, M. (2016). Professional Identity: Concept analysis using Rodger's evolutionary method. Acta Medica Mediterranea International Scientific Journal of Clinical Medicine, 32(1111-1114).

Fagerberg, I., \& Kihlgren, M. (2001). Experiencing a nurse identity: the meaning of identity to Swedish registered nurses 2 years after graduation. Journal of Advanced Nursing, 34(1), 137-145. 
Hoeve, Y. T., Jansen, G., \& Roodbol, P. (2014). The nursing profession: Public image, self-concept and professional identity. A discussion paper. Journal of Advanced Nursing, 70(2), 295-309.

Al Jarrah, I. A. T. (2013). Associate nursing students' perceptions toward nursing profession in Jordan. European Scientific Journal, 9(6), 147-166

Johnson, M., Cowin, L. S., Wilson, I., \& Young, H. (2012). Professional identity and nursing: contemporary theoretical developments and future research challenges. International nursing review, 59(4), 562-569.

Kanefuji, A., \& Nakatani, H. (2017). Structure of professional identity of public health nurses working for governmental agencies. Health, 9(13), 1776-1786.

Kabeel, A. R. A., \& Eisa, S. A. E. M. M. (2017). Relationship between job satisfaction and professional identity among psychiatric nurses. Egyptian nursing journal, 14(1), 9.

Masih, S., \& Gulzar, L. (2016). Nurses' Self Perception about their Public Image in a Metropolitan City, Karachi. Journal of the Dow University of Health Sciences (JDUHS), 10(2), 70-74.

Mohtashami, J., Rahnama, H., Farzinfard, F., Talebi, A., Atashzadeh-Shoorideh, F., \& Ghalenoee, M. (2015). A survey of correlation between professional identity and clinical competency of psychiatric nurses. Open Journal of Nursing, 5(09), 765.

McCarthy, D. (1996). Knowledge as culture: the new sociology of knowledge. _Retrived from. "http $/ /$ www.infoseek.com"_www.infoseek.com "http://www.infoseek.com"_www.infoseek.com_.

Baker, S. (2011). Outcomes and Competencies for Graduates of Practica/Vocational, Diploma, Associate Degree, Baccalaureate, Master's, Practice Doctorate, and Research Doctorate Programs in Nursingdeveloped by the National League for Nursing; New York: National League for Nursing, 2010; 96 pages, \$29.95 (NLN members), \$34.95 (nonmembers)(soft cover). Nursing Education Perspectives, 32(3), 201. 
Patidar, A. B., Kaur, J., Sharma, S. K., \& Sharma, N. (2011). Future nurses' perception towards profession and carrier plans: A cross sectional survey in state Punjab. Nursing and Midwifery Research Journal, 7(4). :175-186.

Poorchangizi B., Farokhzadian J., Abbaszadeh A., Mirzaee M., and Borhani .(2017). The importance of professional values from clinical nurses' perspective in hospitals of a medical university in Iran ; BMC Med Ethics. 2017 Mar 1;18(1):20. doi: 10.1186/s12910-017-0178-9

Wolf, L. E. (2007). A study of socialization of accelerated BSN graduates (Doctoral dissertation, Kent State University)

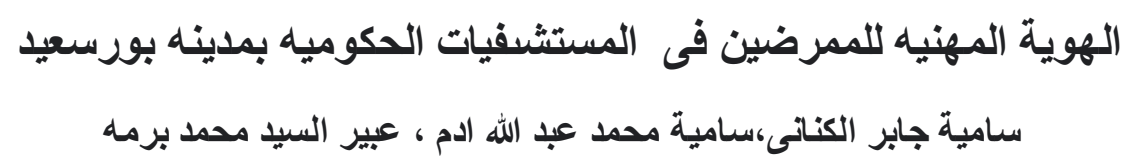

\section{الخلاصة}

الخلفية: الهوية المهنية أساسية لممارسة التمريض وتضع الأساس لوضوح الطابع المهني على التمريض. الهدف: هو تقييم الهوية المهنية بين الممرضين في مدينة بورسعيد. الموضوعات والطريقة: تم استخدام التصميم الوصفي لإجراء هذه الدراسة. شملت عينة الدراسة جميع الممرضين (360 ممرض و ممرضة) بمستشفى بورسعيد العام ومستشفى الزهور العام. تم جمع البيانات باستخدام أداة واحدة ؛ تنقسم إلى قسمين ، مقياس الهوية المهنية واستبيان البيانات الثخصية. النتائج: أظهرت نتائج هذه الدراسة أن حوالي ثلاثة أرباع الممرضين الخاضعين للاراسة كانت لديهم صورة مهنية مرضية ، كما أن المجال الحازم كان مرضيا ، وأن غالبية المررضين راضين عن المسؤولية الذاتية. الخلاصة: خلصت الدراسة إلى أن: كان إجمالي الممرضين الخاضعين للار اسة مستوى مرضٍٍ بشكل عام. علاوة على ذلك ، كانت هناك علاقة ذات دلالة إحصائية بين العمر وسنوات الخبرة للممرضين مع مقياس الهوية المهنية العام. التوصيات: أوصت الدراسة بضرورة جعل العاملين بمهنة التمريض مسؤولين بشكل فردي عن تدريبهر ، وزيادة قدرتهم على التعلم وإضافة إلى معارفهم ، كمورد لا غنى عنها للنمو الشخصي والمهني. أيضًا ، يجب أن نأخذ المرضى في الاعتبار للار اسات القادمة. الكلمات المرشدة : الهوية المهنية للممرضين ، المستشفيات الحكوميه. 